\title{
Furan fatty acids efficiently rescue brain cells from cell death induced by oxidative stress $\uparrow$
}

Cite this: Food Funct., 2013, 4, 1209

\author{
Antoinette Teixeira, Ruud C. Cox and Maarten R. Egmond*
}

\begin{abstract}
Treatment of rat brain C6 astroglioma cells with furan fatty acid F6 prior to exposure to hydrogen peroxide shows a strong protective effect of F6 against cell death resulting from oxidative stress. This protective effect is obtained only for F6 administered as a free fatty acid and with an intact furan ring. It is proposed that brain cells are rescued by F6 scavenging radicals elicited by lipid peroxidation within the cell membrane. Oxidative processes outside the cell membrane, such as protein carbonylation, are not affected by F6. Furan fatty acids such as those present in fish oils and marine organisms are likely beneficial for consumption in reducing the risk of diseases that have been implicated to arise from oxidative stress, such as Alzheimer's disease.
\end{abstract}

Received 8th March 2013

Accepted 5th May 2013

DOI: 10.1039/c3fo60094g

www.rsc.org/foodfunction

\section{Introduction}

Oxidative stress in cells giving rise to reactive oxygen species (ROS), peroxides and free radicals is known to be involved in a wide range of pathological conditions, such as neuro-degeneration, ${ }^{1}$ aging, ${ }^{2}$ cardiovascular disease and diabetes. ${ }^{3}$ Particularly brain tissue and the nervous system in general are prone to oxidative stress due to high metabolic turnover and the presence of highly unsaturated fatty acids. Generation of ROS in cells and mechanistic aspects have been investigated extensively (for a review see e.g. Novo and Parola ${ }^{4}$ ). Defence against ROS in the context of health and nutrition has already been an important issue in functional food science for many years. ${ }^{5}$ While evidence is mounting that control of such oxidative processes is essential to curb detrimental conditions, ${ }^{6}$ compounds that efficiently interfere in situ with ROS and free radical products are hard to find. Consumption of large quantities of antioxidant vitamins, such as vitamins A, C or E is not effective or even harmful. Successful applications of low doses of antioxidants have been reported, e.g. to modulate inflammatory and oxidative stress in diabetes, ${ }^{7}$ but controversy remains, ${ }^{8}$ although it is clear that ROS production and inflammatory processes are tightly linked. ${ }^{9}$ Also treatment of Alzheimer's disease with antioxidants is under study, ${ }^{10}$ but results are inconclusive. The generation and protective effects of heat shock proteins (Hsp) in response to heat, chemical stress

Department of Membrane Biochemistry and Biophysics, Bijvoet Center, University of Utrecht, Padualaan 8, 3584CH Utrecht, The Netherlands. E-mail: m.r.egmond@uu. nl; Tel: +31302533526

$\dagger$ Electronic supplementary information (ESI) available. See DOI: 10.1039/c3fo60094g

\$ Present address: Department of Medical Oncology, Universiteitsweg 100, Stratenum 2233, 3584CG Utrecht, The Netherlands. E-mail: a.vandendikkenberg@umcutrecht.nl. conditions or disease ${ }^{\mathbf{1 1}}$ have been well documented ( $c f$. review Hsp70 (ref. 12)). Unfortunately, antioxidants such as vitamin E tend to decrease the levels of Hsp70 (ref. 13), thereby inducing apoptosis. This suggests that these antioxidants may reduce the extent of oxidative stress, but apparently do not help cells to overcome the detrimental consequences of the stress conditions. Strategies using anti-apoptotic drugs have recently been defined aiming at preventing neurodegenerative diseases. ${ }^{14}$ Such therapies include the application of statins, GSK3 $\beta$ inhibitors and cell cycle inhibitors. Furan fatty acids as likely effective radical scavengers in lipid peroxidation processes are not mentioned here. ${ }^{15}$ Furthermore, furanoids (particularly benzofurans ${ }^{16}$ ) have been reported to inhibit b-amyloid aggregation, while the anti-inflammatory action of furan derivatives through inhibition of COX-2 has been described. ${ }^{17}$ This prompted us to study the influence of the furan fatty acid on rat brain C6 astroglioma cells put under oxidative stress using hydrogen peroxide. ROS thus generated are considered to be relevant for in vivo production of ROS involving lipoxygenase metabolites. ${ }^{18} \mathrm{C} 6$ cells are known to play a major role in the defence against several types of insult ${ }^{19}$ and respond to injury by altering their phenotype. Astroglial cells have often been used in studies on neuronal apoptosis, ${ }^{20}$ while astroglial atrophy has been implicated in early dementia. ${ }^{21}$ We find that administration of the furan fatty acid to C6 cells leads to powerful protection against oxidative stress.

\section{Materials and methods}

\section{Chemicals}

All chemicals were of reagent grade unless stated otherwise. Furan fatty acid F6 (12,15-epoxy-13,14-dimethyleicosa-12,14dienoic acid) was a gift from AnalytiCon Discovery GmbH. 


\section{Cell culture and experimental design}

A rat glioma C6 cell line (ATCC cat nr CCL-107) was grown in pyruvate free DMEM with high glucose, supplemented with 5\% fetal bovine serum, at $37{ }^{\circ} \mathrm{C}$ in a humidified $10 \% \mathrm{CO}_{2}$ atmosphere. No antibiotics were used. To avoid altered susceptibility of the C6 cells to peroxide-induced oxidative stress, ${ }^{29}$ the continual cell line was never allowed to pass $70 \%$ confluence or passage number 47 (starting at passage number 37). Cells were seeded either in $100 \mathrm{~mm}$ or $35 \mathrm{~mm}$ dishes and allowed to grow until about $85 \%$ confluence. Cells were exposed to F6 fatty acid in serum free medium supplemented with F6 in the form of an ammonia emulsion, or bound to fatty acid free BSA for up to 5 hours before $\mathrm{H}_{2} \mathrm{O}_{2}$ insult. Incubations with $\mathrm{H}_{2} \mathrm{O}_{2}$ were performed in serum free medium for 1 hour, followed by $24 \mathrm{~h}$ recovery in normal growth medium. Cell lysates were obtained from the $100 \mathrm{~mm}$ dishes after washing twice with ice cold PBS containing protease inhibitors (PI). Excess PBS was removed and the cells were lysed in the smallest possible leftover volume by 20 passages through a $26 \mathrm{G}$ needle while kept on ice. The 35 $\mathrm{mm}$ dishes were used to determine cell viability using the MTT assay. Cells were heat shocked by placing parafilm sealed dishes in a water bath on a lead block for 30 minutes, and allowed to recover in a $\mathrm{CO}_{2}$ incubator for 24 hours before preparing cell lysates. Samples of the culture medium were taken after exposure of the cells to $\mathrm{F} 6$ and $\mathrm{H}_{2} \mathrm{O}_{2}$, and after the $24 \mathrm{~h}$ recovery time, to determine lactate dehydrogenase leakage. The cell lysates were divided in aliquots to prevent unnecessary thawing and refreezing, and stored at $-80{ }^{\circ} \mathrm{C}$ together with the culture medium samples until further analysis.

Images of cell cultures were taken on a Nikon Eclipse TE2000-U microscope ( $4 \times$ occular, $40 \times$ lens magnification) after growing cells on Mattek glass bottom dishes.

\section{MTT viability assay}

Cell proliferation was measured by conversion of the tetrazolium salt MTT (3-(4,5-dimethylthiazol-2-yl)-2,5-diphenyl-tetrazolium bromide) to strongly blue colored formazan by mitochondrial dehydrogenase activity. ${ }^{22}$ During the last $2 \mathrm{~h}$ of the $24 \mathrm{~h}$ recovery time after stress, $0.5 \mathrm{mg} \mathrm{ml}^{-1}$ MTT tetrazolium salt in PBS was added to the cells. After $2 \mathrm{~h}$ the medium was removed, and $0.5 \mathrm{ml}$ DMSO was added for 15 minutes at room temperature, under light agitation, to solubilise cells and formazan. The amount of formazan produced was calculated using a molar extinction coefficient of $\varepsilon=36300 \mathrm{M}^{-1} \mathrm{~cm}^{-1}$, after measurement at $570 \mathrm{~nm}$.

\section{LDH leakage assay}

The assay is based on the conversion of pyruvate to lactate by LDH. The decrease of absorption of NADH in time was monitored at $340 \mathrm{~nm}$. Cell lysates were diluted to equal protein content in PBS, and $100 \mu \mathrm{l}$ samples were transferred to microtiter plates. Reactions were monitored for 15 minutes after addition of $0.8 \mathrm{mM}$ pyruvate and $0.65 \mathrm{mM} \mathrm{NADH}$, while rates were calculated from the linear parts of the progress curves.
From these rates the distribution of $\mathrm{LDH}$ over cell lysates and medium was calculated.

\section{SDS-PAGE and Western blotting}

Cell lysate samples in SDS loading buffer were heated to $95{ }^{\circ} \mathrm{C}$ for 5 minutes. Subsequently, DNA was destroyed by 8 passages through a $26 \mathrm{G}$ needle, after which samples were loaded on $10 \%$ SDS gels. Equal amounts of protein were loaded in each lane in equal volumes (volumes corrected with loading buffer). After transfer to a PVDF membrane by electroblotting, the blots were blocked in PBS containing $0.2 \%$ tween 20 (PBST) for 30 minutes at room temperature. Subsequently the blots were incubated with an $\alpha$ Hsp70 alkaline phosphatase conjugate for 1 hour at room temperature in PBST (antibody: Hsp70/72 mAb (C92F3A) AP conjugate, Enzo Life Sciences). After 3 washes in PBST, three washes in PBS and 3 washes in Tris-Saline-Magnesium (TSM) buffer the immuno complexes were visualized using nitro blue tetrazolium (NBT) and 5-bromo-4-chloro-3-indolylphosphate (BCIP) in TSM buffer.

\section{Protein carbonylation assay}

The extent of protein carbonylation was determined after treatment of carbonyl groups with 2,4-dinitrophenylhydrazine (DNPH) to form stable hydrazone products (DNP) and detection with a monoclonal anti-DNP antibody conjugated to Alkaline Phosphatase ( $\alpha$ DNP-AP monoclonal mouse IgE). Carbonylated proteins were detected after SDS-PAGE and Western blotting of cell lysates on a PVDF membrane, using NBT/BCIP as a substrate for the AP conjugate. To further quantify the increase in protein carbonylation, ELISAs were performed using the same antibody, but with pNPP as a substrate using an adaptation of the methods described by Buss and Winterbourn ${ }^{23}$ and Levine et al. $^{24}$

DNA was removed from the cell lysates by precipitation with $1 \%$ streptomycin sulfate. Subsequently the protein was precipitated with $20 \%$ TCA and redissolved in $6 \mathrm{M}$ guanidine $\mathrm{HCl}$ with $10 \mathrm{mM}$ DNPH, $\mathrm{pH} 2.5$, to a protein concentration of $1 \mathrm{mg} \mathrm{ml}^{-1}$. After 45 minutes of incubation at RT in the dark (vortexing every 10 minutes), the samples were diluted in coating buffer $(10 \mathrm{mM}$ $\left.\mathrm{Na}_{2} \mathrm{HPO}_{4}, 150 \mathrm{mM} \mathrm{NaCl}, \mathrm{pH} 7\right)$ to 10,5 and $2.5 \mu \mathrm{g}$ of protein per $100 \mu \mathrm{l}$ and absorbed to immunosorp plates overnight at $4{ }^{\circ} \mathrm{C}$. The plates were thoroughly washed with PBS-ethanol $1: 1$ and PBS before blocking with 5\% Protifar in PBS $\left(1.5 \mathrm{~h}, 37^{\circ} \mathrm{C}\right)$. After washing with PBS containing 0.1\% tween 20 (PBST) the plates were incubated with $\alpha$-DNP-AP monoclonal mouse IgE $1: 10000$ in $5 \%$ Protifar in PBST $\left(1.5 \mathrm{~h}, 37^{\circ} \mathrm{C}\right)$. Carbonylated proteins were detected using pNPP as a substrate $\left(1 \mathrm{~h}, 37^{\circ} \mathrm{C}\right)$ and measuring E405 $\mathrm{nm}$. All incubations were performed using $100 \mu \mathrm{l}$ per well and all wash steps using $200 \mu \mathrm{l}$ per well.

\section{Hydrogenation of furan fatty acid F6}

The furan ring in $\mathrm{F} 6$, the fatty acid $\left(\mathrm{C}_{22} \mathrm{H}_{38} \mathrm{O}_{3}\right)$ was hydrogenated essentially as described before ${ }^{25}$ yielding the corresponding dihydrofuran-F6 species. The identity of this product as sodium salt (mass 375.5) or potassium salt (mass 391.4) was verified using LC-MS analysis. 


\section{Reduction of F6 carboxylic acid}

The carboxylate group of $\mathrm{F} 6$ fatty acid $(15 \mathrm{ml})$ was reduced by

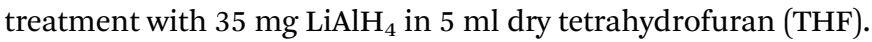
After complete conversion excess $\mathrm{LiAlH}_{4}$ was removed by addition of water. After acidification with $\mathrm{HCl}(2.5 \%)$ the final product was extracted using ether, lyophilized and subsequently taken up in ethanol. The remaining salts were removed by centrifugation. The identity of the final product as an F6 aldehyde was derived from LC-MS (mass 334.4).

\section{Esterification of F6}

F6 fatty acid $(15 \mathrm{ml})$ was treated with $1 \mathrm{ml}$ thionylchloride in 10 $\mathrm{ml}$ methanol under gentle refluxing of the solvent for 45 minutes. The F6 methyl ester formed was washed several times with methanol and lyophilized to remove $\mathrm{SO}_{2}$ and HCL. The identity of the product was checked by LC-MS (mass 363.4).

\section{Stability of $\mathrm{F} 6$ in the presence of $\mathrm{H}_{2} \mathrm{O}_{2}$}

The stability of F6 fatty acid in the presence of high levels of hydrogen peroxide was investigated by incubation for several days with $2 \mathrm{mM} \mathrm{H}_{2} \mathrm{O}_{2}$. Formation of reaction products was tested using thin layer chromatography.
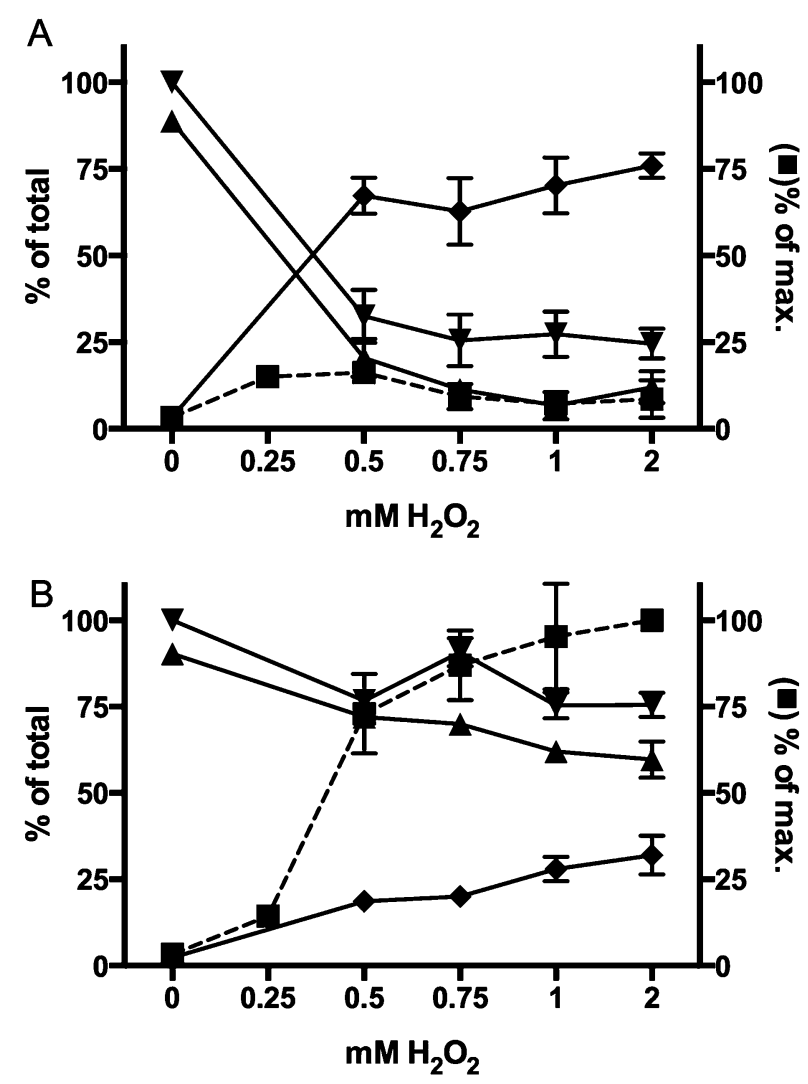

Fig. 1 C6 cell viability for cells under oxidative stress generated by $\mathrm{H}_{2} \mathrm{O}_{2}$ without F6 (top, A) and after pre-incubation with $50 \mu \mathrm{M}$ F6 (bottom, B). LDH within cells $(\boldsymbol{\Delta})$ and leaked out $(\bullet)$; MTT assay $(\boldsymbol{\nabla})$; left $Y$-axis: data plotted relative to total $\mathrm{LDH}$ and $\mathrm{MTT}$, respectively, at $0 \mathrm{mM} \mathrm{H}_{2} \mathrm{O}_{2}$; right $Y$-axis: $\mathrm{Hsp} 70$ levels ( $\mathbf{a}$ ) relative to a maximum $\mathrm{Hsp} 70$ level obtained after pre-incubation with $\mathrm{F} 6$ and at $2 \mathrm{mM} \mathrm{H}_{2} \mathrm{O}_{2}$.

\section{BCA protein determination}

The protein concentration in the cell lysates was measured with the Bicinchoninic Acid assay kit purchased from Thermo Fischer, using a microtiter plate reader, with a BSA calibration curve as a reference.

\section{Statistics}

Statistical analysis (2-way ANOVA) and graphing were performed using Prism GraphPad software. The experiments were repeated for 4-7 times. SEM (standard error of the mean) values are indicated as error bars in Fig. 1, 4 and 5. All data were found to be statistically relevant with $p$-values $<0.0001$.

\section{Results}

In cell culture dishes rat brain $\mathrm{C} 6$ astroglioma cells were subjected to oxidative stress generated by $\mathrm{H}_{2} \mathrm{O}_{2}$ ( $1 \mathrm{~h}$ incubation).

Fig. 1A shows survival data for $\mathrm{C} 6$ control cells, while Fig. 1B represents results for cells pre-incubated with furan fatty acid F6.

This fatty acid was added as an emulsion or mixed with fatfree BSA (0-15 mM). Within experimental errors the presence of BSA did not affect the results (loading controls are available as ESI Fig. $1 \dagger$ ). Without F6 strong leakage of intracellular LDH and a strong drop in mitochondrial dehydrogenase activity (MTT assay) point to poor cell survival.

The amounts of Hsp70 formed in response to this stress condition are very modest indeed, particularly when compared to cells pre-incubated with F6. As shown in Fig. 1B only modest LDH leakage is found, while mitochondrial dehydrogenase activity only drops slightly. In addition, the Hsp70 response is much stronger, nearly one order of magnitude higher than without F6.

Fig. 2 shows a series of images of C6 cells exposed to $2 \mathrm{mM}$ $\mathrm{H}_{2} \mathrm{O}_{2}$ and pre-incubated with increasing concentrations of

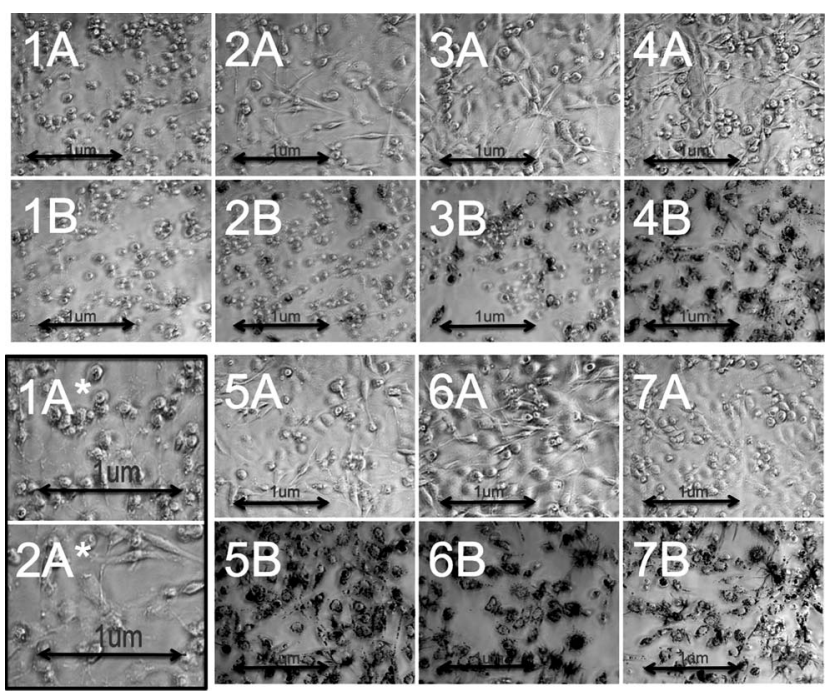

Fig. 2 Images of $\mathrm{C} 6$ cells exposed to $2 \mathrm{mM} \mathrm{H}_{2} \mathrm{O}_{2}$ and pre-incubated with increasing F6 concentration. Panels 1A-7A: no MTT staining and panels 1B-7B MTT stained. Panels $1 A *$ and $2 A *$ are magnifications of $1 A$ and $2 A$, respectively. $F 6$ levels: 1A, B: $0 \mu \mathrm{M}$; 2A, B: $1 \mu \mathrm{M}$; 3A, B: $5 \mu \mathrm{M}$; 4A, B: $10 \mu \mathrm{M} ; 5 \mathrm{~A}, \mathrm{~B}: 20 \mu \mathrm{M} ; 6 \mathrm{~A}, \mathrm{~B}: 50$ $\mu \mathrm{M}$; 7A, B: $100 \mu \mathrm{M}$. Arrows represent $1 \mu \mathrm{m}$. 
furan fatty acid F6. MTT staining is used to identify live cells, whereas cell shape is better observed without staining. Interestingly, already $1 \mu \mathrm{M}$ F6 is sufficient to counter cell death, as several cells show a positive MTT stain in panel 2B, but not in $1 \mathrm{~B}$ (0 $\mu \mathrm{M}$ F6).

Based on MTT staining protection against oxidative stress is optimal between 20 and $50 \mu \mathrm{M}$ F6. It should be noted that the images in Fig. 2 are representative of the status of at least $85 \%$ of all cells in the experiments. Oxidative stress leads to morphological changes of C6 cells (cell rounding) and cell death (MTT stain absent). Cell rounding is shown in panel $1 \mathrm{~A}^{*}$ and much less in panel $2 A^{*}$. At higher magnification (ESI $\dagger$ Fig. 2) MTT stainnegative cells can be clearly identified as apoptotic cells.

F6 and $\mathrm{H}_{2} \mathrm{O}_{2}$ are administered separately in the above experiments, but direct contact between these compounds cannot be excluded. We observed that F6 stored in $2 \mathrm{mM} \mathrm{H}_{2} \mathrm{O}_{2}$ for 3 weeks is fairly stable $(10-20 \%$ oxidation products). This partially oxidized F6 (diluted to $50 \mu \mathrm{M}$ ) was incubated with C6 cells and still showed strong protection against oxidative stress.

\section{F6 modification}

Several modifications of F6 were made to further probe the role of furan fatty acids in preventing oxidative stress. First, the furan ring was hydrogenated yielding dihydro-F6 (Fig. 3). Although the furan ring still contains one double bond the aromatic character is lost. Further hydrogenation to a tetrahydro-furan species requires harsh conditions ${ }^{25}$ and was not carried out. Other modifications of F6 were directed towards the carboxylate group. This group was esterified to yield a methyl-ester and also reduced to an aldehyde after treatment with $\mathrm{LiAlH}_{4}$.

The incubations of C6 cells with F6 and modified F6 species are summarized in Fig. 4. Cell viability is shown in Fig. 4A for MTT assays only, but similar results were obtained for the LDH assays used.

Our data show that partial hydrogenation of the furan ring of F6 completely abolishes the high Hsp70 induction and protection against oxidative stress as observed for F6. To our surprise, also modifications of the carboxylic group of F6 (F6 aldehyde, F6 Me-ester) lead to a drastic loss of protection against oxidative stress.

\section{Protein carbonylation}

Incubation of $\mathrm{C} 6$ cells with $\mathrm{H}_{2} \mathrm{O}_{2}$ gives rise to dose dependent protein carbonylation as observed by using an antibody against DNPH derivatized protein (for a review see e.g. ref. 26).

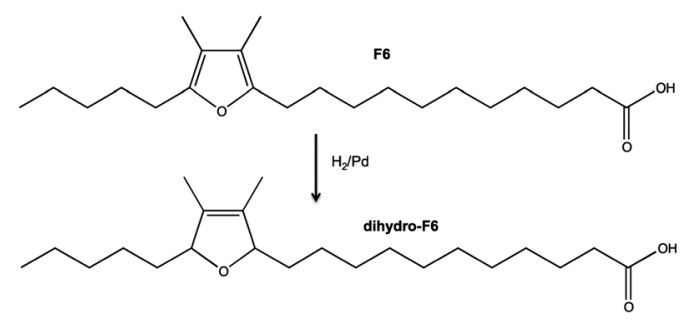

Fig. 3 Hydrogenation of F6 to yield dihydro-F6.
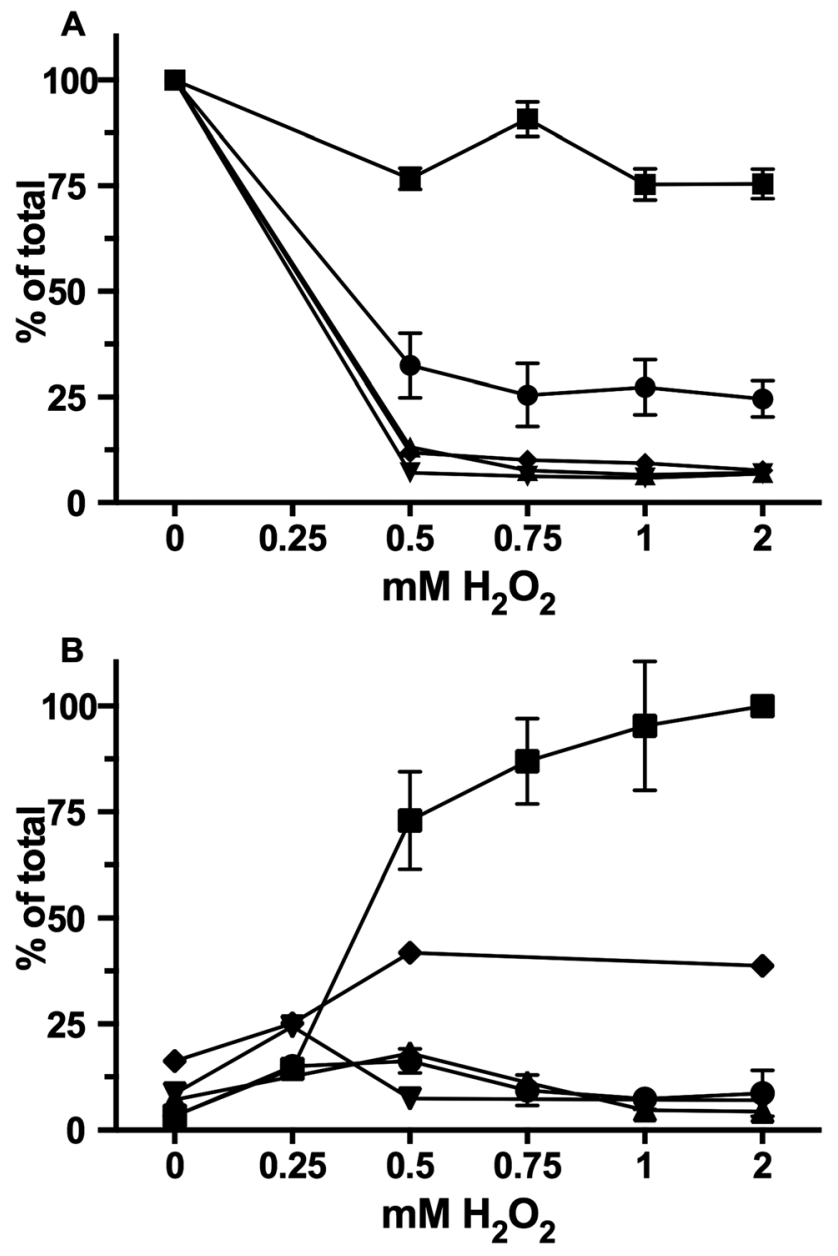

Fig. 4 The influence of F6 and modified F6 species on $\mathrm{C} 6$ cell viability A: MTT assay and $\mathrm{B}$ : $\mathrm{Hsp} 70$ production for cells under oxidative stress induced by $\mathrm{H}_{2} \mathrm{O}_{2} ; Y$ axes as in Fig. 1; $50 \mu \mathrm{M} \mathrm{F6} \mathbf{\square} ; 50 \mu \mathrm{M}$ dihydro-F6 $\mathbf{\Delta} ; 50 \mu \mathrm{M} \mathrm{F6}$ aldehyde $\bullet ; 50 \mu \mathrm{M}$ F6 Me-ester $\mathbf{\nabla} ; 0 \mu \mathrm{M}$ F6:

Fig. 5 summarises ELISA assays carried out to quantify the extent of protein carbonylation directly after the stress conditions or after $24 \mathrm{~h}$ recovery of the cells. Oxidative stress leads to

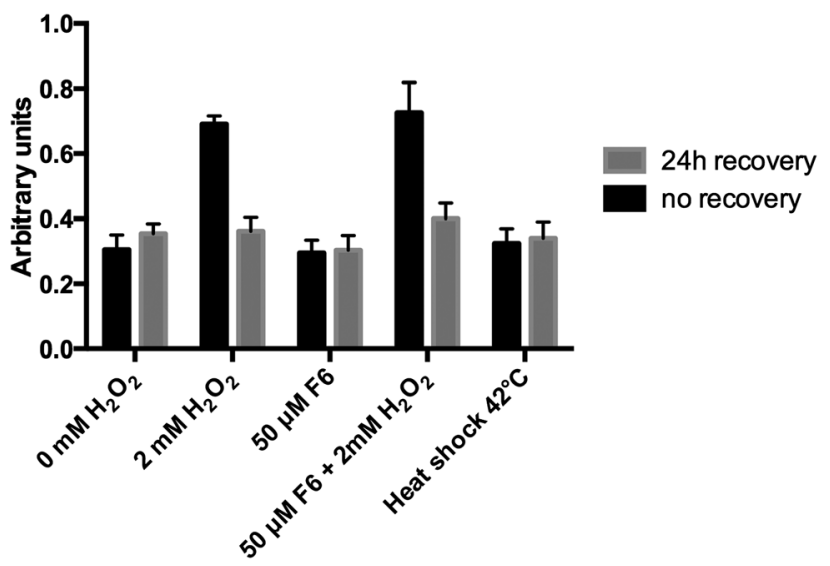

Fig. 5 Relative amounts of carbonylated proteins in C6 cells under various stress conditions. 
an immediate increase in the level of carbonylated proteins, but most of this material is cleared after $24 \mathrm{~h}$ recovery of the C6 cells. Prior exposure of C6 cells to F6 on its own does not lead to any significant amount of carbonylated protein. Furthermore, the presence of F6 does not affect the amount of carbonylated protein seen after $\mathrm{H}_{2} \mathrm{O}_{2}$ exposure. Also a heat shock of C6 cells at $42{ }^{\circ} \mathrm{C}$ does not lead to any increase in carbonylated proteins.

\section{Discussion}

Oxidative stress in C6 astroglioma cells induced by hydrogen peroxide has already been studied extensively for many years. We have used this system as a model to assess the effect of furan fatty acids to counter the negative consequences of oxidative stress in cells. As shown in Fig. 1A cell viability drops rapidly with increasing $\mathrm{H}_{2} \mathrm{O}_{2}$ concentrations, while $60-80 \%$ of the cells leak $\mathrm{LDH}$ above $0.5 \mathrm{mM} \mathrm{H}_{2} \mathrm{O}_{2}$. This corresponds well with previous work ${ }^{27 a}$ pointing to $60 \%$ apoptosis reached for $\mathrm{C} 6$ cells incubated for $1 \mathrm{~h}$ with $1 \mathrm{mM} \mathrm{H}_{2} \mathrm{O}_{2}$. It should be noted that sensitivity towards hydrogen peroxide depends on the culture conditions used ${ }^{27 b}$ and must be carefully controlled. When C6 cells are pre-incubated with $50 \mu \mathrm{M}$ F6 subsequent exposure to peroxide shows strongly improved cell viability (Fig. 1B). At $2 \mathrm{mM} \mathrm{H}_{2} \mathrm{O}_{2} \mathrm{LDH}$ leakage drops from $80 \%$ in the absence of $\mathrm{F} 6$ to less than $40 \%$ for cells treated with F6. An even stronger effect of furan fatty acid F6 was observed after a semi-quantitative analysis of Hsp70 induction. As shown in Fig. 1B Hsp70 levels do increase with higher peroxide up to a maximum value at $2 \mathrm{mM} \mathrm{H}_{2} \mathrm{O}_{2}$. Data are plotted relative to the highest $\mathrm{Hsp} 70$ response value obtained. In the absence of $\mathrm{F} 6$ only about $10 \%$ of this maximum response value is seen for Hsp70 induction. This modest response is in line with previous studies ${ }^{28}$ showing that Hsp70 induction in response to oxidative stress is much lower than that upon heat stress. We verified that Hsp70 induction in the absence of F6 is only $5 \%$ of that after a heat shock (at $42{ }^{\circ} \mathrm{C}$; data not shown). It should be noted that the strong boost of Hsp70 levels in the presence of F6 is not due to F6 alone. Most likely, the positive effect of the furan fatty acid on cell viability allows more cells to recover from the stress condition leading to higher Hsp70 levels. This protective effect is very powerful indeed as pre-incubation with $1 \mu \mathrm{M}$ F6 is sufficient for some cells to survive in $2 \mathrm{mM} \mathrm{H}_{2} \mathrm{O}_{2}$ (Fig. 2) In order to investigate how and where in the cell furan fatty acids like $\mathrm{F} 6$ may give rise to protection against oxidative stress we have modified F6 in several ways. First, we observed that partial hydrogenation of the furan ring to yield dihydro-F6 completely blocked the production of Hsp70 as observed for F6 itself and substantially reduced cell viability (Fig. 4). The requirement of a fully functional furan species in F6 implies that the protection against ROS induced membrane leakage and mitochondrial dysfunction arises from quenching lipid peroxidation processes in the cell through radical scavenging. ${ }^{15}$ We wondered whether the limited success of antioxidants to slow down lipid peroxidation and inflammatory processes could arise from the fact that most antioxidants poorly dissolve in the membrane environment. Lipid peroxyl (ROO) radicals formed during peroxidation chain reactions exhibit long lifetimes in their membrane environment thus being effective in sustaining chain reactions, while most radicals are short-lived in water. ${ }^{29}$ We obtained indirect proof that the protective effect of furan species is most effective against oxidative stress when present in a membrane environment. Reduction of F6 fatty acid to an aldehyde blocks uptake of this furan species by esterification in cellular phospholipids and leads to lower cell viability under oxidative stress as compared to intact F6 fatty acid. The very poor protective effect of F6 fatty acid methyl ester most likely arises from the insufficient uptake of fatty methyl esters by C6 cells, but poor subsequent incorporation of F6 species into membrane phospholipids cannot be excluded. In summary, we conclude that optimal radical scavenging is obtained for furan fatty acid species when esterified in membrane phospholipids. This explains that furan fatty acids indeed outperform other antioxidants, such as vitamin E. ${ }^{30}$

Protein carbonylation has been described extensively to arise from direct oxidation of lysine, arginine, threonine and proline residues (primary oxidation) as well as via aldehydes formed during lipid peroxidation chain reactions (secondary oxidation). ${ }^{26}$ As shown in Fig. 5 we have quantified the extent of protein carbonylation induced by hydrogen peroxide under our conditions. It appears that carbonylated proteins are rapidly formed, but cleared completely during the $24 \mathrm{~h}$ recovery period. Thus, by itself protein carbonylation appears not to be lethal to the cell. In addition we find that F6 does not affect protein carbonylation at all. Since F6 most likely interferes with lipid peroxidation processes it can also be concluded that lipid peroxidation products are not a likely source for the bulk of carbonylated proteins in $\mathrm{C} 6$ cells during oxidative stress induced by $\mathrm{H}_{2} \mathrm{O}_{2}$.

Oxidized phospholipids play an important role e.g. in the innate immunity system involving the scavenger receptor CD36 (ref. 31). Interestingly, furanoids that are formed as byproducts of lipid peroxidation in brain tissue are not recognized for clearance by CD36 (ref. 32). This perhaps implies a special role for furanoid species in response to oxidative stress conditions, which is in line with our finding that Hsp70 levels are increased in the presence of furan fatty acid F6. This increase in Hsp70 production is important as Hsp70 has been implicated as an activator of the human complement system, ${ }^{33}$ while the complement system is beneficial in the early stages of inflammatory response. ${ }^{34}$ Overall, our findings on the potent protective role of furan fatty acids when cells are subjected to oxidative stress provides promising opportunities for application in fighting diseases such as Alzheimer's disease.

\section{Conclusions}

Cell death as observed by cell leakage or mitochondrial dysfunction of C6 astroglioma cells after exposure to hydrogen peroxide was strongly reduced when cells were first treated with furan fatty acid F6. The protective effect seen already at fairly low F6 levels $(1 \mu \mathrm{M})$ was lost after partial hydrogenation of the furan ring of F6. This prompted the conclusion that protection by F6 against oxidative stress in C6 astroglioma cells is due to its radical scavenging properties. Furthermore, modifications of 
the carboxylic group of F6 were also found to abolish protection against oxidative stress. This was taken to indicate that F6 is fully functional when present in a membrane environment after trans-esterification to membrane phospholipids.

Furan fatty acids such as those present in fish oils and marine organisms are likely beneficial for consumption in reducing the risk of diseases that have been implicated to arise from oxidative stress, such as Alzheimer's disease.

\section{References}

1 B. Halliwell, Oxidative stress and neurodegeneration: where are we now?, J. Neurochem., 2006, 97(6), 1634-1658.

2 (a) G. Perry, A. D. Cash and M. A. Smith, Alzheimer Disease and Oxidative Stress, J. Biomed. Biotechnol., 2002, 2(3), 120123; (b) G. Perry, A. Nunomura, A. D. Cash, M. A. Taddeo, K. Hirai, G. Aliev, J. Avila, T. Wataya, S. Shimohama, C. S. Atwood and M. A. Smith, Reactive oxygen: its sources and significance in Alzheimer disease, J. Neural Transm., Suppl., 2002, 62, 69-75; (c) G. Perry, A. Nunomura, K. Hirai, X. Zhu, M. Perez, J. Avila, R. J. Castellani, C. S. Atwood, G. Aliev, L. M. Sayre, A. Takeda and M. A. Smith, Is oxidative damage the fundamental pathogenic mechanism of Alzheimer's and other neurodegenerative diseases?, Free Radical Biol. Med., 2002, 33(11), 1475-1479.

3 J. S. Johansen, A. K. Harris, D. J. Rychly and A. Ergul, Oxidative stress and the use of antioxidants in diabetes: linking basic science to clinical practice, Cardiovasc. Diabetol., 2005, 4(1), 5.

4 E. Novo and M. Parola, Redox mechanisms in hepatic chronic wound healing and fibrogenesis, Fibrog. Tissue Repair, 2008, 1(1), 5.

5 A. T. Diplock, J. L. Charleux, G. Crozier-Willi, F. J. Kok, C. Rice-Evans, M. Roberfroid, W. Stahl and J. Vina-Ribes, Functional food science and defence against reactive oxidative species, Br. J. Nutr., 1998, 80(suppl. 1), S77-S112.

6 R. G. Cutler, Oxidative stress profiling: part I. Its potential importance in the optimization of human health, Ann. N. Y. Acad. Sci., 2005, 1055, 93-135.

7 B. Garcia-Bailo, A. El-Sohemy, P. S. Haddad, P. Arora, F. Benzaied, M. Karmali and A. Badawi, Vitamins D, C, and $\mathrm{E}$ in the prevention of type 2 diabetes mellitus: modulation of inflammation and oxidative stress, Biologics, 2011, 5, 7-19.

8 S. Golbidi, S. A. Ebadi and I. Laher, Antioxidants in the treatment of diabetes, Curr. Diabetes Rev., 2011, 7(2), 106125.

9 M. Genestra, Oxyl radicals, redox-sensitive signalling cascades and antioxidants, Cell. Signalling, 2007, 19(9), 1807-1819.

10 M. Grundman and P. Delaney, Antioxidant strategies for Alzheimer's disease, Proc. Nutr. Soc., 2002, 61(2), 191-202.

11 J. Chung, A. K. Nguyen, D. C. Henstridge, A. G. Holmes, M. H. Chan, J. L. Mesa, G. I. Lancaster, R. J. Southgate, C. R. Bruce, S. J. Duffy, I. Horvath, R. Mestril, M. J. Watt, P. L. Hooper, B. A. Kingwell, L. Vigh, A. Hevener and M. A. Febbraio, HSP72 protects against obesity-induced insulin resistance, Proc. Natl. Acad. Sci. U. S. A., 2008, 105(5), 1739-1744.

12 M. P. Mayer and B. Bukau, Hsp70 chaperones: cellular functions and molecular mechanism, Cell. Mol. Life Sci., 2005, 62(6), 670-684.

13 (a) P. L. Hooper and J. J. Hooper, Vitamin E and atherosclerosis, Prev. Cardiol., 2004, 7(3), 144; (b) E. El Golli, W. Hassen, A. Bouslimi, C. Bouaziz, M. M. Ladjimi and $\mathrm{H}$. Bacha, Induction of Hsp 70 in vero cells in response to mycotoxins cytoprotection by sub-lethal heat shock and by vitamin E, Toxicol. Lett., 2006, 166(2), 122-130.

14 F. X. Sureda, F. Junyent, E. Verdaguer, C. Auladell, C. Pelegri, J. Vilaplana, J. Folch, A. M. Canudas, C. B. Zarate, M. Palles and A. Camins, Antiapoptotic drugs: a therapeutic strategy for the prevention of neurodegenerative diseases, Curr. Pharm. Des., 2011, 17(3), 230-245.

15 (a) G. Spiteller, Is lipid peroxidation of polyunsaturated acids the only source of free radicals that induce aging and agerelated diseases?, Rejuvenation Res., 2010, 13(1), 91-103; (b) G. Spiteller, The important role of lipid peroxidation processes in aging and age dependent diseases, Mol. Biotechnol., 2007, 37(1), 5-12; (c) G. Spiteller, Peroxyl radicals: inductors of neurodegenerative and other inflammatory diseases. Their origin and how they transform cholesterol, phospholipids, plasmalogens, polyunsaturated fatty acids, sugars, and proteins into deleterious products, Free Radical Biol. Med., 2006, 41(3), 362-387; (d) G. Spiteller, Is atherosclerosis a multifactorial disease or is it induced by a sequence of lipid peroxidation reactions?, Ann. N. Y. Acad. Sci., 2005, 1043, 355-366; (e) G. Spiteller, The relation of lipid peroxidation processes with atherogenesis: a new theory on atherogenesis, Mol. Nutr. Food Res., 2005, 49(11), 999-1013; (f) D. C. White, R. Geyer, A. D. Peacock, D. B. Hedrick, S. S. Koenigsberg, Y. Sung, J. He and F. E. Loffler, Phospholipid furan fatty acids and ubiquinone-8: lipid biomarkers that may protect dehalococcoides strains from free radicals, Appl. Environ. Microbiol., 2005, 71(12), 8426-8433.

16 H. D. Choi, P. J. Seo, B. W. Son and B. W. Kang, Synthesis of 2-(4-hydroxyphenyl)benzofurans and their application to beta-amyloid aggregation inhibitor, Arch. Pharmacal Res., 2004, 27(1), 19-24.

17 (a) E. S. Lee, B. C. Park, S. H. Paek, Y. S. Lee, A. Basnet, D. Q. Jin, H. G. Choi, C. S. Yong and J. A. Kim, Potent analgesic and anti-inflammatory activities of 1-furan-2-yl-3pyridin-2-yl-propenone with gastric ulcer sparing effect, Biol. Pharm. Bull., 2006, 29(2), 361-364; (b) S. Shahapurkar, T. Pandya, N. Kawathekar and S. C. Chaturvedi, Quantitative structure activity relationship studies of diaryl furanones as selective COX-2 inhibitors, Eur. J. Med. Chem., 2004, 39(10), 899-904.

18 C. Kim, J. Y. Kim and J. H. Kim, Cytosolic phospholipase $\mathrm{A}(2)$, lipoxygenase metabolites, and reactive oxygen species, BMB Rep., 2008, 41(8), 555-559.

19 V. W. Pentreath and N. D. Slamon, Astrocyte phenotype and prevention against oxidative damage in neurotoxicity, Hum. Exp. Toxicol., 2000, 19(11), 641-649. 
20 H. Satoi, H. Tomimoto, R. Ohtani, T. Kitano, T. Kondo, M. Watanabe, N. Oka, I. Akiguchi, S. Furuya, Y. Hirabayashi and T. Okazaki, Astroglial expression of ceramide in Alzheimer's disease brains: a role during neuronal apoptosis, Neuroscience, 2005, 130(3), 657-666.

21 (a) J. J. Rodriguez, M. Olabarria, A. Chvatal and A. Verkhratsky, Astroglia in dementia and Alzheimer's disease, Cell Death Differ., 2009, 16(3), 378-385; (b) A. Verkhratsky, M. Olabarria, H. N. Noristani, C. Y. Yeh and J. J. Rodriguez, Astrocytes in Alzheimer's disease, Neurotherapeutics, 2010, 7(4), 399-412.

22 Y. Liu, D. A. Peterson, H. Kimura and D. Schubert, Mechanism of cellular 3-(4,5-dimethylthiazol-2-yl)-2,5diphenyltetrazolium bromide (MTT) reduction, $J$. Neurochem., 1997, 69(2), 581-593.

23 I. H. Buss and C. C. Winterbourn, Protein carbonyl measurement by ELISA, Methods Mol. Biol., 2002, 186, 123-128.

24 R. L. Levine, D. Garland, C. N. Oliver, A. Amici, I. Climent, A. G. Lenz, B. W. Ahn, S. Shaltiel and E. R. Stadtman, Determination of carbonyl content in oxidatively modified proteins, Methods Enzymol., 1990, 186, 464-478.

25 M. Maris, W.-R. Huck, T. Mallat and A. Baiker, Palladiumcatalyzed asymmetric hydrogenation of furan carboxylic acids, J. Catal., 2003, 219, 52-58.

26 Y. J. Suzuki, M. Carini and D. A. Butterfield, Protein carbonylation, Antioxid. Redox Signaling, 2010, 12(3), 323-325.

27 (a) M. Marangolo, M. M. Mc Gee, K. F. Tipton and D. C. Williams, Oxidative stress induces apoptosis in C6 glioma cells: involvement of mitogen-activated protein kinases and nuclear factor kappa B, Neurotoxic. Res., 2001, 3, 397-409; (b) S. Brenner, M. Gülden, E. Maser and H. Seibert, Lasting effect of preceding culture conditions on the susceptibility of C6 cells to peroxide-induced oxidative stress, Toxicol. in Vitro, 2010, 24(8), 2090-2096.

28 (a) A. Gosslau and L. Rensing, Induction of Hsp68 by oxidative stress involves the lipoxygenase pathway in C6 rat glioma cells, Brain Res., 2000, 864(1), 114-123; (b) A. Gosslau, P. Ruoff, S. Mohsenzadeh, U. Hobohm and L. Rensing, Heat shock and oxidative stress-induced exposure of hydrophobic protein domains as common signal in the induction of hsp68, J. Biol. Chem., 2001, 276(3), 1814-1821.

29 W. A. Pryor, Oxy-radicals and related species: their formation, lifetimes, and reactions, Annu. Rev. Physiol., 1986, 48, 657-667.

30 G. Spiteller, Furan fatty acids: occurrence, synthesis, and reactions. Are furan fatty acids responsible for the cardioprotective effects of a fish diet?, Lipids, 2005, 40(8), 755-771.

31 S. L. Hazen, Oxidized phospholipids as endogenous pattern recognition ligands in innate immunity, J. Biol. Chem., 2008, 283(23), 15527-15531.

32 S. Gao, R. Zhang, M. E. Greenberg, M. Sun, X. Chen, B. S. Levison, R. G. Salomon and S. L. Hazen, Phospholipid hydroxyalkenals, a subset of recently discovered endogenous CD36 ligands, spontaneously generate novel furan-containing phospholipids lacking CD36 binding activity in vivo, J. Biol. Chem., 2006, 281(42), 31298-31308.

33 Z. Prohaszka, M. Singh, K. Nagy, E. Kiss, G. Lakos, J. Duba and G. Fust, Heat shock protein 70 is a potent activator of the human complement system, Cell Stress Chaperones, 2002, 7(1), 17-22.

34 (a) P. Gasque, Y. D. Dean, E. P. McGreal, J. VanBeek and B. P. Morgan, Complement components of the innate immune system in health and disease in the CNS, Immunopharmacology, 2000, 49(1-2), 171-186; (b) P. Gasque, J. W. Neal, S. K. Singhrao, E. P. McGreal, Y. D. Dean, B. J. Van and B. P. Morgan, Roles of the complement system in human neurodegenerative disorders: pro-inflammatory and tissue remodeling activities, Mol. Neurobiol., 2002, 25(1), 1-17. 